\title{
SISTEMA E SISTEMAS NA LITERATURA "COLONIAL"1
}

\author{
Anco Márcio Tenório Vieira ${ }^{2}$ \\ ancovieira@yahoo.com.br
}

Desde os anos vinte dos Oitocentos que a questão da autonomia literária brasileira vem arregimentando os estudiosos do que denominamos, há dezoito décadas, de literatura brasileira. Entre as diversas "metodologias" propostas, a de Antonio Candido, em sua Formação da literatura brasileira (1959), foi a mais definidora para os estudos literários. Obra basilar, trazendo em seu título a palavra que, segundo Paulo Eduardo Arantes (1997, p. 11), se tornou uma "verdadeira obsessão nacional" - Formação -, o livro de Candido fomentou não somente seguidores que a enriqueceram com novos estudos, como também críticas que se firmaram e se firmam não menos importantes. Dentre elas, duas estão entre as mais relevantes: Conceito de literatura brasileira (196o), de Afrânio Coutinho, e O Sequestro do barroco na formação da literatura brasileira: o caso Gregório de Matos (1989), de Haroldo de Campos. Vamos aos textos.

\footnotetext{
1 Este ensaio é uma versão resumida de um estudo mais extenso que desenvolvemos sobre Formação da literatura brasileira, de Antonio Candido, e que deverá ser publicado em livro ainda este ano.

2 Anco Márcio Tenório Vieira é professor do Programa de Pós-Graduação em Letras da UFPE.
} 
Estudando "a formação da literatura brasileira como síntese de tendências universalistas e particularistas", Candido (1981, p. 23) distingue "manifestações literárias" - encontradas nos três primeiros séculos da colonização brasileira - de "literatura propriamente dita”. Esta, assinala, se dá por um "um sistema de obras ligadas por denominadores comuns, que permitem reconhecer as notas dominantes de uma fase”. Além desse sistema de obras ligadas por denominadores comuns - o uso da língua e de determinados temas e imagens ("características internas") - Candido nota que são também "denominadores comuns" "certos elementos de natureza social e psíquica, embora literariamente organizados, que se manifestam historicamente e fazem da literatura aspecto orgânico da civilização". Como aspecto orgânico da civilização, os denominadores comuns seguem um modelo triádico: a produção - "conjunto de produtores literários, mais ou menos conscientes do seu papel” -; a recepção - "conjunto de receptores, formando os diferentes tipos de público, sem os quais a obra não vive" -; e, por último, a transmissão - "mecanismo transmissor (de modo geral, uma linguagem, traduzida em estilos), que liga uns a outros".

Para Candido (1981, pp. 23-24), a conjunção desses três elementos vai constituir "um tipo de comunicação inter-humana - a literatura - que aparece, sob este ângulo, como sistema simbólico, por meio do qual as veleidades mais profundas do indivíduo se transformam em elementos de contacto entre os homens, e de interpretação das diferentes esferas da realidade". Só dessa forma é que se institui "a formação da continuidade literária - espécie de transmissão da tocha entre corredores, que assegura no tempo o movimento conjunto, definindo os lineamentos de um todo". Essa "transmissão da tocha" firma uma tradição. No caso, uma transmissão de um conjunto de ideias pensadas ("uma linguagem, traduzida em estilo") por determinados homens (os escritores) para outros homens (leitores, ou futuros escritores). Ideias que tanto podem ser acatadas quanto rejeitadas, mas que, num caso ou noutro, irão suscitar reflexões. Mais: fazem nascer uma "literatura propriamente dita". A ausência dessa tradição, afirma Candido, implica na inexistência de uma literatura: seja enquanto "fenômeno de civilização", seja enquanto "sistema de obras ligadas por denominadores comuns". 
Dentro desse modelo triádico, qualquer publicação que não se insira nessa "concepção estrutural" não pode ser acatada como "literatura propriamente dita" - literatura "como fenômeno de civilização" -, mas apenas como manifestação literária. Como nota Marisa Lajolo:

Para a teoria em função da qual se desenvolve este conceito de sistema literário, literatura não pode ser concebida como (apenas) uma determinada categoria de textos, tornados literários por traços que lhe são intrínsecos. Ou seja, estabelecida a noção de sistema literário como fundadora e fiadora da literatura, o conceito do que é ou do que não é 'literário' deixa de identificar-se exclusivamente como procedimentos internos ao texto. Decorrência possível da aceitação da noção de sistema literário como condicionante da literariedade de um texto, é a literatura passar a ser concebida como uma determinada categoria do sistema pelo qual circulam (LAJOLO, 2003, p.53).

É dentro desse pressuposto que Candido (1981, p. 25) vai datar a formação da literatura brasileira, a formação de um sistema, no ano de 1750 (uma data, segundo ele, "puramente convencional") tomando como "ponto de partida” a Academia Brasílica dos Renascidos (Bahia, 1759-6o), a Academia dos Seletos (Rio de Janeiro, 1752-54) e os primeiros poemas de Cláudio Manuel da Costa. Como exemplo das inúmeras manifestações literárias, ele cita o teatro e os versos do padre José de Anchieta, a Academia Brasílica dos Esquecidos (Bahia, 1724-25), a Academia dos Felizes (Rio de Janeiro, 1736-1740), a obra do padre Antônio Vieira e o exemplo mais polêmico de todos: Gregório de Matos e Guerra (e aqui peço desculpa pela longa citação):

(...) embora tenha permanecido na tradição local da Bahia, ele [Gregório de Matos] não existiu literariamente (em perspectiva histórica) até o Romantismo, quando foi redescoberto, sobretudo graças a [Francisco Adolfo de] Varnhagen; e só depois de 1882 e da edição [Alfredo do] Vale Cabral pôde ser devidamente avaliado. Antes disso, não influiu, não contribuiu para formar o nosso sistema literário, e tão obscuro permaneceu sob os seus manuscritos, que [Diogo] Barbosa Machado, o minucioso erudito da Biblioteca Lusitana (1741-1758), ignora-o completamente, embora registre quanto João de Brito e Lima pôde alcançar (CANDIDO, 1981, p. 24).

Para adentrarmos melhor nos procedimentos que formam os "denominadores comuns" e "as notas dominantes de uma fase" em um dado "sistema" literário que, no caso, é o brasileiro, faz-se necessário recorrer a um texto mais teórico de Candido - Literatura e sociedade (1965) -, particularmente o ensaio "Crítica e sociologia (tentativa de 
esclarecimento)", que encerra tanto os princípios que calçam a sua crítica quanto refletem os dilemas que foram trilhados pela teoria literária do século XX:

(...) antes procurava-se mostrar que o valor e o significado de uma obra dependiam de ela exprimir ou não certo aspecto da realidade, e que este aspecto constituía o que ela tinha de essencial. Depois, chegou-se à posição oposta, procurando-se mostrar que a matéria de uma obra é secundária, e que a sua importância deriva das operações formais postas em jogo, conferindolhe uma peculiaridade que a torna de fato independente de quaisquer condicionamentos, sobretudo social, considerado inoperante como elemento de compreensão (CANDIDO, 200o, p. 4, grifo nosso).

Colocado o dilema entre as duas linhas interpretativas que vinham pautando o século XX - as correntes formalistas versus a sociologia da literatura de raiz oitocentista -, Candido expõe sua posição teórico-crítica e, por desdobramento, em quais bases deve se fundamentar a análise literária:

Hoje sabemos que a integridade da obra não permite adotar nenhuma dessas visões dissociadas; e que sóa podemos entender fundindo texto e contexto numa interpretação dialeticamente íntegra, em que tanto o velho ponto de vista que explicava pelos fatores externos, quanto o outro, norteado pela convicção de que a estrutura é virtualmente independente, se combinam como momentos necessários do processo interpretativo. Sabemos, ainda, que o externo (no caso, o social) importa, não como causa, nem como significado, mas como elemento que desempenha um certo papel na constituição da estrutura, tornando-se, portanto, interno (CANDIDO, 200o, p. 4).

Defendida a "integridade da obra" por meio da urdidura entre texto e contexto, Candido evoca uma das suas filiações teóricas - o Georg Lukács hegeliano -, particularmente um ensaio que este escrevera em 1914, no qual lemos a seguinte indagação: “o elemento histórico-social possui, em si mesmo, significado para a estrutura da obra, e em que medida?' ou 'seria o elemento sociológico na forma dramática apenas a possibilidade de realização do valor estético (...) mas não determinante dele?”' (apud CANDIDO, 200o, pp. 4-5). Candido responde cada uma dessas inquirições, ao tempo em que verticaliza sua posição:

(...) quando estamos no terreno da crítica literária somos levados a analisar a intimidade das obras, e o que interessa é averiguar que fatores atuam na organização interna, de maneira a constituir uma estrutura peculiar. Tomando o fator social, procuraríamos determinar se ele fornece apenas matéria (ambiente, costumes, traços grupais, ideias), que serve de veículo para conduzir a corrente criadora (nos termos de Lukács, se apenas possibilita a realização 
do valor estético); ou se, além disso, é elemento que atua na constituição do que há de essencial na obra enquanto obra de arte (nos termos de Lukács, se é determinante do valor estético). (CANDIDO, 200o, p. 5)

Para exemplificar como se dá o processo em que o externo (o meio social) é um elemento constituidor na estrutura da obra (o interno), Candido analisa Senhora, de José de Alencar, que, em conclusão, leva-o a afirmar:

\begin{abstract}
Quando fazemos uma análise deste tipo, podemos dizer que levamos em conta o elemento social, não exteriormente, como referência que permite identificar, na matéria do livro, a expressão de uma certa época ou de uma sociedade determinada; nem como enquadramento, que permite situá-lo historicamente; mas como fator da própria construção artística, estudado no nível explicativo e não ilustrativo. Neste caso, saímos dos aspectos periféricos da sociologia, ou da história sociologicamente orientada, para chegar a uma interpretação estética que assimilou a dimensão social como fator de arte. Quando isto se dá, ocorre o paradoxo assinalado inicialmente: o externo se torna interno e a crítica deixa de ser sociológica, para ser apenas crítica (CANDIDO, 2000, p. 7).
\end{abstract}

Exposto os procedimentos de análise e de interpretação, Candido (20oo, p. 7) conclui que "Uma crítica que se queira integral deixará de ser unilateralmente sociológica, psicológica ou linguística, para utilizar livremente os elementos capazes de conduzirem a uma interpretação coerente. Mas nada impede que cada crítico ressalte o elemento da sua preferência, desde que o utilize como componente da estruturação da obra" (grifo nosso).

Todo esse conjunto de princípios teóricos e metodológicos nos leva a concluir que: $1^{\circ}$ - para Candido, os procedimentos de composição da narrativa e da forma literária não vêm da tradição literária ou do mito, como defendiam muitos dos que faziam parte do New Criticism, a exemplo de um Northrop Frye (2000), muito menos o conteúdo de um livro é secundário, prevalecendo tão somente as operações intrínsecas, formais, resultando numa imanência artística da obra, independente "de quaisquer condicionamentos, sobretudo social". Os procedimentos de composição da narrativa e da forma literária são frutos da integridade entre "texto e contexto numa interpretação dialeticamente íntegra"; $2^{\circ}$ - é na urdidura entre texto e contexto que se encontra tanto a "interpretação dialeticamente íntegra" quanto a "literatura propriamente dita". Se um "sistema" se caracteriza por "obras ligadas por denominadores comuns, que permitem reconhecer as notas dominantes de uma fase", esses 
"denominadores comuns" são construídos por procedimentos narrativos e formais historicamente situados. Logo, uma dada literatura nacional, mesmo sendo constituída pela "síntese de tendências universalistas e particularistas", só se faz de fato nacional quando o texto e o contexto moldam localmente as tendências universalistas e lhes dão, por meio das regras das composições poéticas e narrativas, "formas literárias" que permitem seu reconhecimento como uma dada literatura autonomamente nacional; $3^{\circ}$ - as "manifestações literárias" são ainda uma extensão das tendências universalistas na colônia, onde o contexto ainda não se tornou um "componente da estruturação da obra". Assim, não constituem um "sistema de obras ligadas por denominadores comuns", que mimetizaram um dado contexto sócio-histórico-nacional.

\section{III}

A primeira reação aos pressupostos teórico e metodológico de Candido veiode um dos mais combativos críticos literáriosdo Brasil:Afrânio Coutinho. Responsável, entre 1955 e 1959, pela direção, organização e publicação de A literatura no Brasil (obra, em quatro tomos, com mais de cinquenta colaboradores; entre eles, Candido), Coutinho busca mapear e encerrar todos os movimentos, escolas, gêneros e formas literárias que frutificaram no Brasil, expondo a matéria dentro de um critério que buscasse privilegiar uma periodização estilística ou estético-literária. Ainda em 1960 ele publica outro livro não menos ambicioso: Conceito de literatura brasileira. Seu objetivo não é apenas definir o que seja uma literatura brasileira, mas responder teórico-metodologicamente ao citado estudo de Candido.

Introdutor, no Brasil, do New Criticism, Coutinho (1981, p. 13) vinha, desde os anos 40, opondo-se tanto à chamada "crítica impressionista", então praticada nos jornais brasileiros, quanto às histórias literárias que abordavam seu objeto como "epifenômeno da vida social e política". Contrapondo-se às análises que privilegiam o contexto em detrimento do texto, ele, em prefácio ao seu livro Correntes cruzadas (1953), ${ }^{3}$ vai se

\footnotetext{
3 Correntes cruzadas encerra os artigos que Coutinho publicara no Diário de Notícias, do Rio de Janeiro, entre 1948 e 1953. O título da obra é o mesmo da sua então coluna de crítica literária. A este livro seguiu Da crítica e da nova crítica, publicado em 1957, e que reúne os artigos da citada coluna publicados entre 1953 e 1957.
} 
insurgir e, em contrapartida, tomar para si o dever de orientar a crítica literária brasileira nos seus estudos de literatura. Pouco simpático ao "predomínio do método histórico", Coutinho lembra, no entanto, que:

Isso não significa, todavia, o abandono das contribuições históricas, mas apenas a colocação do método histórico em seu devido lugar, que não é, na consideração da literatura, o primeiro. A crítica é, acima de tudo, crítica poética, no sentido aristotélico, e a história só vale na medida em que é um auxiliar na compreensão da obra, um meio e não um fim, e um meio útil às vezes, por vezes perturbador, e nem sempre indispensável. Para a "nova crítica", o movimento de âmbito universal que forma hoje a tendência dominante, o que importa, sobretudo, é a obra, o texto, e na análise do texto - de poesia ou de prosa - se especializam as várias escolas, buscando o difícil núcleo, o intrínseco, que forma a essência estética da obra de arte literária. Aos métodos de análise extrínseca, ela ajunta e sobrepõe os métodos da análise intrínseca (COUTINHO, 1987, p. 24).

Complementando sua tese, assinala que não pertencem ou estão fora da interpretação análises de orientação historicistas, psicológicas, sociológicas, biológicas e marxistas. Para ele,

(...) todas essas escolas críticas, surgidas na reação ao impressionismo subjetivista, consideram a obra literária somente como resultado de certas forças naturais, e seu interesse dirige-se apenas para o fato (fatualismo ou fenomenalismo), isto é, o documento histórico, sociológico ou psicológico, a ser verificado, descrito e rotulado (COUTINHO, 1987, p. 29).

\section{Em contraposição a todas essas "escolas críticas" ainda predominantes} em sua época, Coutinho reafirma sua filiação teórica à crítica que é, "acima e antes de tudo, crítica poética, no sentido aristotélico”, pois, para ele:

O grande mestre da crítica literária científica é Aristóteles, que deixou na Poética as normas para o assunto. O primeiro passo é a correta observação do fato literário, na sua intimidade, ou intrínseco do fato literário; a análise de seus elementos (com todos os recursos disponíveis), a descrição e classificação desses elementos, isolados ou combinados; o estudo de seus processos de produção e recepção, e, por último, o julgamento de seu valor. Sem julgamento não há crítica, e nisso a crítica distingue-se da ciência. Mas para julgar, o crítico necessita de um corpo de critérios ou padrões objetivos, o que faz que a crítica não possa ser verdadeiramente crítica enquanto permanecer no plano impressionista, incompatível com o juízo de valor, pois o impressionismo é subjetivista e relativista na sua fidelidade à impressão sensível, à emoção (COUTINHO, 1987, p. 30). 
Concluindo seu raciocínio, Coutinho volta-se para os pressupostos do historicismo literário oitocentista - leia-se Sílvio Romero, Araripe Júnior e José Veríssimo. O acerto de contas com a tríade clássica da crítica brasileira delineia os caminhos distintos entre a escola teórica abraçada por ele e aquela que não apenas lhe antecedeu, mas, de algum modo, ainda ditava as linhas programáticas da crítica brasileira:

O erro da crítica de orientação sociológica determinista foi acreditar na explicação genética do meio, da raça e do momento. Sabemos quão superada está a teoria de Taine e dos críticos que nele se inspiraram. Os fatores extrínsecos não têm o monopólio da formação artística, nem mesmo a importância que se lhes atribuiu. Podem estar ou não presentes na gênese da obra e não satisfazem de todo quando pretendem explicar a natureza do produto estético. Por si não passam, quando estão presentes, de meros elementos condicionantes, incapazes de esgotarem o mistério da criação artística (COUTINHO, 1987, p. 33).

É visível, no conjunto da sua obra, a defesa teórica de um projeto de crítica literária e, de maneira inusitada, a realização de outro diverso do que advogara. Sua crítica, não raras vezes, troca o principal (os objetivos estético-estilísticos, a perspectiva estético-literária: texto) pelo ancilar (os tais aspectos políticos-históricos-literários que ele próprio condena: contexto), e perde-se em posições ideológicas que o aproximam dos já então "superados" e combatidos críticos do século XIX. Um exemplo, particularmente do que ele entende por um "conceito de literatura brasileira”, é a retomada, como ferramenta teórica, do conceito de “obnubilação brasílica”, cunhado em 1886, por Araripe Júnior. O crítico cearense defendia que no estudo da literatura no primeiro século da colonização, "pouco ou nada importam (...) as influências étnicas [como defendia Sílvio Romero], que só vêm a mostrar-se, de modo sensível, do século XVII por diante, em Gregório de Matos e outros”. Excluindo, em princípio, a tese do evolucionismo social e, em contraposição, adotando o naturalismo determinista de Hippolyte Taine - com sua propagada fórmula de "raça", "meio" e "momento" - Araripe afirma que o meio físico, o segundo tópico da tríade taineana (e não a miscigenação), vai exercer, nos colonos que aqui vão aportando ao longo do século XVI, uma "ação catalítica", uma "quimificação [na sua] psicose”. Essa "Quimificação”, ou "obnubilação brasílica”, é tão grande "que chega a assombrar o observador, por sua obra de neutralização temporária de hábitos de raça, princípios de educação, ideias religiosas, de tudo, enfim, quanto pode constituir o 
pecúlio de um povo que envia aventureiros através de mares nunca dantes navegados" (ARARIPE, 1958, p. 494).

Perseguindo também esse conceito de base determinista, Coutinho afirma:

\begin{abstract}
A literatura brasileira não começou no momento arcádico-romântico [como defende Candido]. Vem de antes, partiu do instante em que o primeiro homem europeu aqui pôs o pé, aqui se instalou, iniciando uma nova realidade histórica, criando novas vivências, que traduziu em cantos e contos populares, germinando uma nova literatura. Naquele instante, criou-se um homem novo, "obnubilando", como queria Araripe Júnior, o homem antigo, o europeu. Foi o homem brasileiro (COUTINHO, 1981, p. 38, grifo nosso).
\end{abstract}

Apesar de defender "um homem novo" que termina por germinar "uma nova literatura" nos trópicos, Coutinho (1987, p. 37) nota que "talvez por uma questão de temperamento racial não tenhamos as qualidade intelectuais e psicológicas para nos dedicar à produção de grandes obras”. Se a assertiva parece estranha, pois, urdindo raça e cultura, remete-nos aos pressupostos cientificistas do século XIX, talvez ela nos explique a sua defesa da já então superada e controvertida tese da obnubilação. Tese que não somente acusava a "quimificação" que, no Brasil, o meio teria exercido nos europeus e africanos, mas da qual Coutinho lançava mão também para explicar o fato do Brasil ainda não ter oferecido à literatura universal "grandes obras".

Perseguindo o conceito de Araripe, Coutinho (1981, p. 42) afirma que "A literatura brasileira 'formou-se' com o barroco. Com o arcadismoromantismo, tornou-se autônoma. Com o modernismo atingiu a maioridade". Dentro desse processo "evolutivo", ele aborda um aspecto da formação da literatura brasileira que firma o processo de obnubilação e, por sua vez, já sinaliza para a sua autonomia literária: a língua.

Sendo a autonomia literária um conceito romântico, nada lhe parece ser mais determinante para a alteridade do seu discurso ante outras formações de literaturas nacionais (além da cor local e da nacionalidade do escritor) do que a língua - questão, no caso brasileiro, não menos problemática quando sabemos que a língua acolhida para se construir essa literatura é a que foi legada pelo colonizador. Ciente desse gargalo conceitual que entrou na ordem do dia com os românticos, argumenta que 
A língua autônoma só não basta, pois há várias literaturas independentes expressas na mesma língua. Mais importante que a língua é o uso que dela se faz, é a fala que ela produz. A existência de um mesmo idioma, embora sejam cada vez mais radicais e crescentes as divergências entre os falares português e brasileiro, não impediu a diversificação literária, desde cedo, entre Brasil e Portugal (COUTINHO, 1981, p. 14, grifo nosso).

Coutinho (1981, p. 11) afirma que mesmo concordando com a Filologia, segundo a qual não existe "nenhuma violentação à estrutura tradicional no português que no Brasil se fala e escreve”, bastaria colocar uma página de um escritor moderno brasileiro ao lado de outra de um escritor português para que se perceba a diferença. Diferença que não apenas se restringe ao vocabulário, mas se faz sentir no "torneio de frase, revelador de tendências expressionais peculiares, de acordo com uma sensibilidade e psicologia desenvolvida no curso dos embates da história através da formação de uma nova civilização" (grifo nosso). Civilização esta, frise-se, que até o presente momento não tinha, segundo ele, produzido "grandes obras".

Por ser uma crítica que se encaminha antes para o campo ideológico do que para o analítico, o exemplo de Coutinho pouco resiste a um exame mais acurado. Se a tese é que no instante em que o português colocou os pés no Brasil ele sofreu um processo de obnubilação e, por sua vez, toda a literatura produzida aqui passa a ser distinta, na sua forma literária, da portuguesa, a pergunta é: em que momento se assinala os inícios desse "torneio de frase"? A resposta não é fácil. A questão se problematiza quando sabemos que a escola teórica na qual Coutinho se inscreve se atém à análise intrínseca do texto, defendendo que a forma literária não vem da experiência social do autor, mas da própria tradição literária. Logo, o assinalado "torneio de frase" só poderia advir da experiência sóciohistórica do autor, e não da própria tradição literária. Por outro lado, se quisermos considerar o contexto como constituidor da forma literária, algumas questões precisam ser problematizadas. Vejamos.

Se existe uma distinção entre o português falado e o culto, não existe nenhuma cesura significativa entre o modo de escrever o português culto tanto aquém quanto além-mar. É como se o clérigo ou magistrado que, aportado no Brasil, adaptou os seus hábitos de alimentação, vestuário e morada, tivesse, em contrapartida, ficado imune, no momento de escrever, às alterações linguísticas que iam sendo promovidas entre as diversas etnias que aqui aportavam. Fato que Gilberto Freyre (1984, p. 333) viu como "a escrita recusando-se, com escrúpulos de donzelona, ao mais leve contato com a falada”. 
A explicação para tamanha alteridade nos é sinalizada por Antônio Houaiss, quando lembra que até o século XVIII noventa e oito por cento dos que viviam nas sociedades de cultura gráfica eram analfabetos:

\begin{abstract}
Os dois por cento, oficiais do mesmo ofício, em geral, se prezavam mutuamente. Esse dois por cento correspondiam aos que, em geral, por nascimento (mas não exclusivamente), estavam titulados a serem scholares, quer dizer, os que tinham direito à scholaritas - a qualidade e faculdade dos que podiam ou eram ou haviam sido instruídos. Para os 98 por cento restantes, reconhecia-se, quando necessário, o saber vivido, a velhice temperada, o senso do equilíbrio, a experiência sofrida, a resignação proverbiada; e mesmo esses atributos não eram buscados: buscava-se, apenas, nos vividos, o que estes podiam transmitir em saberes experimentados (HOUAISS, 1985, p.9).
\end{abstract}

Ora, se a média no mundo (em particular, na Europa) era de dois por cento de alfabetizados, no Brasil a realidade era muito menos generosa: apenas meio por cento da população, nos primeiros três séculos da colonização, sabia ler e escrever. ${ }^{4}$ Esses homens - e algumas raríssimas mulheres - faziam parte de uma "elite" que representava a extensão da Metrópole na Colônia, de uma ideologia estamental - a da colonização que tinha que ser preservada.

Na língua, a modalidade portuguesa aprendida nos bancos escolares da Universidade de Coimbra e no Colégio de Évora, continuava sendo a prestigiada entre os raros scholares. Se o português falado no Brasil continuou, ao longo dos primeiros três séculos, recebendo empréstimos lexicais das línguas africanas e indígenas - fazendo com que muitos falantes fossem bilíngues ou triglotas -, o mesmo não se registra no português fixado no papel, muito menos (e este é o ponto que está em questão) nas obras literárias (exceção para os topônimos, os nomes próprios, a designação dos alimentos, das plantas e animais).

Em estudo sobre a burocracia jurídica na Bahia dos séculos XVII e XVIII, Stuart B. Schwartz (1979, p. 57) nota que existiam documentos burocráticos que revelavam desvios da norma culta. No entanto, eram textos que sinalizavam antes a inabilidade de quem os escreveu para manejar as regras e as estruturas da língua escrita, do que haver uma intencionalidade de fixar um português distinto da norma. Era o caso daqueles que pertenciam ao terceiro estamento da burocracia: os tabeliães, escrivães, fiscais de portos e comissários de marinha. Situação homóloga

4 Ver Rosa Virgínia Mattos e Silva (2004, p. 40). 
(e que pode ser estendida para o resto do Brasil) vai ser observada por Maria Cristina de Assis Pinto Fonseca (2005 ${ }^{\mathrm{a}}$ p. 213) nas cartas oficiais expedidas nos séculos XVIII e XIX na Paraíba.

Mesmo quando Coutinho (1981, p. 41) evoca em Gregório de Matos "a linguagem da civilização crioula, mestiça, que aqui se plasmava", assinale-se que os poemas que registram empréstimos linguísticos das línguas africanas e indígenas são insignificantes, principalmente quando comparamos com os mais de 700 poemas que são atribuídos a Gregório de Matos. Artur Neiva coligiu na sua obra apenas 65 vocábulos tupis e 20 palavras do léxico africano, predominantemente oriundo do quimbundo (Cf. SPINA, 1995, pp. 46-47).

Sabemos que foi com a independência política do Brasil que floresceu, entre os escritores brasileiros, o sentimento de alteridade e de defesa de uma "língua brasileira" ou "idioma brasileiro", com o resguardo de que "certos hábitos fonéticos peculiares e alguns torneios sintáticos e estilísticos preferenciais dos brasileiros [eram] ignorados ou desusados em Portugal" (PINTO 1986, p. 9). A realidade, afirma Edith Pimentel Pinto, é que "Nunca se pôde, contudo, apresentar qualquer alteração nas classes de palavras, por exemplo, ou no seu jogo de flexões; ou ainda, qualquer subversão que alterasse a rede sintática fundamental, na organização da frase típica portuguesa - em oposição à de outra língua”. Ainda para Pimentel Pinto (1986, p. 10), fazem-se necessárias alterações mais profundas nas variantes do português falado no Brasil para que ele venha a constituir uma língua brasileira, a exemplo do que ocorreu entre o português e o latim. Alterações como "a mudança da natureza do acento; ou do jogo de oposições funcionais, no nível da morfossintaxe”.

Porém, o principal exemplo dado por Coutinho da cesura linguística entre o Brasil e Portugal, recai sobre José Lins do Rego, Jorge Amado e Rachel de Queiroz. Se o exemplo não deixa de ser pertinente, ele também parece apontar algumas insuficiências, já que a sintaxe e o "torneio de frase” que vamos encontrar em José Lins não é o mesmo que está em Jorge Amado. O mesmo podendo-se aferir nas obras dos diversos escritores portugueses do século XX. Ou seja: a cesura existe tanto entre os escritores brasileiros e portugueses - se é que é possível tomá-los como uma unidade amorfa - quanto entre os próprios escritores brasileiros e também entre os próprios portugueses. Indiferente de nacionalidade ou escola literária, a busca de torneios sintáticos e estilísticos próprios é uma das características daqueles que escreveram no século XX. 
Apesar de Coutinho defender o critério estilístico em detrimento dos estudos que acatavam a literatura como "epifenômeno da vida social e política”, ele termina por se voltar mais para o contexto sócio-histórico-cultural do que para o texto em si. Sem se desvencilhar do conceito de autonomia literária, Coutinho (1987, p. 35) torna-se vítima do que ele próprio condenara, ou seja, "a existência de um conflito desesperado entre a crítica e a história literária, com o predomínio absoluto do critério histórico em detrimento do critério crítico". Na sua tese da obnubilação, o contexto torna-se definidor na construção de uma literatura brasileira. Assim, o texto termina por ser um espelho da nova condição histórica vivida pelos portugueses e africanos.

Concluindo, ressalte-se que as questões colocadas por Candido, e que Coutinho parece não ter alcançado, são: $1^{\circ}$ - pouco importa se a literatura produzida em terras brasileiras era fruto ou nãodeum homem "obnubilado" ou mesmo se essa literatura encerrava um "torneio de frase" distinto da que era produzida na Metrópole, e sim se ela constituía "um sistema de obras ligadas por denominadores comuns". É esse sistema que Coutinho não consegue alinhavar nos escritores que escreveram nos primeiros séculos da colonização brasileira; $2^{\circ}$ - o que constitui uma literatura nacional é, segundo Candido, o fato de que dialeticamente o texto e o contexto vão estabelecendo, por meio das regras das composições poéticas e narrativas, "formas literárias" que permitem seu reconhecimento como uma dada literatura autonomamente nacional.

O sequestro do barroco na formação da literatura brasileira: o caso Gregório de Matos (1989), de Haroldo de Campos, é o resultado de uma longa reflexão sobre a "poética sincrônica" e a "função poética da linguagem”. Reflexão estruturada a partir do diálogo estabelecido com as ideias de Ezra Pound e Roman Jakobson, que defendiam uma literatura de "invenção" e, por extensão, uma leitura sincrônica da história da literatura; uma história constituída antes de momentos de rupturas do que de "momentos decisivos".

No ensaio "Poética sincrônica", Campos (1975, p. 205) assinala que "Há duas maneiras de abordar o fenômeno literário. O critério histórico, que se poderia chamar diacrônico, e o critério estético-criativo, que se 
poderia denominar sincrônico".5 Dentro dessa perspectiva sincrônica, Campos (1975, p. 208) defende um novo modo de se organizar a história da literatura brasileira (na verdade, seu propósito inicial é mais modesto: ele prega que se escreva uma Antologia da Poesia Brasileira de Invenção), que fosse da fase colonial ao modernismo (tendo como ponto alto a poesia de Oswald de Andrade), onde os poetas escolhidos tivessem em comum o fato de terem contribuído "para a renovação de formas em nossa poesia, para a ampliação e a diversificação de nosso repertório de informação estética”. Porém, numa posição ainda tributária à historia literária diacrônica, Campos defende que

(...) a tarefa da poética diacrônica é importante, como trabalho de levantamento e demarcação do terreno, e, ao enfatizar-lhe os defeitos e limites, meu desejo é chamar a atenção para outro tipo de poética - a poética sincrônica-, muitíssimo menos praticada, mas cuja função tem um caráter eminentemente crítico e retificador sobre as coisas julgadas da poética histórica. Para o crítico de visada sincrônica não interessa o horizonte abarcante e esteticamente indiferente da visão diacrônica (CAMPOS, 1975, p. 207).

Ao tomar a defesa de uma leitura sincrônica da literatura, Campos está implicitamente se opondo ao critério historicista. Seu intento de uma "História estrutural da literatura" passa por "cortes sincrônicos", tendo como base "um critério de variação de funções, [que] teriam em conta não apenas o 'presente de criação' (produção literária de uma dada época), mas também o seu 'presente de cultura' (a tradição que nela permaneceu viva, as revisões de autores, a escolha e reinterpretação de clássicos)" (CAMPOS, 1975, pp. 214-215).

Essa revisão de autores se voltaria para a poética diacrônica apenas para colher os escritores do passado que, dentro do critério "estético-criativo", permanecem vivos, ao formarem uma espécie de elo entre os escritores que os antecederam e os que advirão. Haveria, assim, uma relação dialética entre as poéticas sincrônicas e diacrônicas. Nessa relação, a poética sincrônica busca, em princípio, como objeto de análise, o que a história diacrônica define como poetas "maiores". Mesmo que entre

\footnotetext{
5 No seu ensaio “Texto e história” (1969), Haroldo de Campos (1976, p. 18) afirma em nota: "Pode-se distinguir mesmo entre uma 'História textual', que toma o texto, caracterizado por seu 'conteúdo informativo' (suas componentes inventivas), como ponto fulcral e privilegia uma visada sincrônica, e a 'História literária', predominantemente cumulativodiacrônica, que considera a literatura no seu sentido convencional".
} 
os ditos "maiores" só alguns poemas fossem acatados, e entre os ditos "menores" muitos tivessem que ser reavaliados e redimensionados em seu valor "estético-criativo":

\begin{abstract}
Em sua transposição literária, o par sincronia/diacronia está em relação dialética em pelo menos dois níveis: a) a operação sincrônica se realiza contra um pano de fundo diacrônico, isto é, incide sobre os dados levantados pela visada histórica, dando-lhes relevo crítico-estético atual; b) a partir de cortes sincrônicos sucessivos é possível fazer-se um traçado diacrônico renovado da herança literária (...) (CAMPOS, 1975, pp. 214-215).
\end{abstract}

Tanto a dicotomia critérios histórico versus estético-criativo (momentos de rupturas) quanto a "função poética" (Jakobson) da linguagem calçarão as reflexões de Campos sobre a obra de Candido. O modelo esquematizado por Jakobson (1991, p. 123) para a comunicação verbal (ou a que seja passível de verbalização) se estrutura a partir da seguinte disposição: "O REMETENTE envia uma MENSAGEM ao DESTINATÁRIO", que para ser compreendida por este "requer um CONTEXTO a que se refere" e "um CÓDIGO total ou parcialmente comum a ambos”. Por fim, para que se estabeleça a comunicação verbal entre o destinatário e o remetente, faz-se necessário a existência de um canal físico, que é o CONTACTO. Para Jakobson (1991, pp. 123-128), "Cada um desses seis fatores determina uma diferente função da linguagem". Mais: cada "estrutura verbal de uma mensagem depende basicamente da função predominante". Sendo assim, O REMETENTE se centra na "função EMOTIVA ou 'expressiva”" (a exemplo da poesia lírica), o DESTINATÁRIO na função CONATIVA (poesia escrita na $2^{\circ}$ pessoa), e o CONTEXTO encerra "a chamada função REFERENCIAL, 'denotativa', 'cognitiva”' (no caso, a poesia épica, em regra escrita na $3^{\circ}$ pessoa). A esse modelo triádico - REMETENTE, CONTEXTO e DESTINATÁRIO -, Jakobson acrescenta a distinção entre dois outros níveis de linguagem: "a 'linguagem-objeto', que fala de objetos, e a 'metalinguagem', que fala da linguagem”. Ou seja, "Sempre que o remetente e/ou o destinatário têm necessidade de verificar se estão usando o mesmo código, o discurso focaliza o Código; desempenha uma função METALINGUÍSTICA (isto é, de glosa)”. No caso da "função poética", que é o que nos interessa aqui, esta se dá no "pendor (Einstellung) para a MENSAGEM como tal, o enfoque por ela própria”.

Subsumindo o esquema de Jakobson no de Candido, temos: o que em Candido é "Produtor" (comunicante, artista), "Receptor" (comunicando, público), "Comunicado" (obra) e "Realidade" ("diferentes esferas da 
realidade”) em Jakobson é, respectivamente, "Remetente”, “Destinatário”, "Mensagem" e "Contexto". "Contacto" e "Código" têm, em ambos, a mesma terminologia.

Numa linha diversa da de Coutinho, Campos (1989, pp. 16-19) vê, na “perspectiva histórica” de Candido, uma "perspectiva ideológica”. Nota que o esquema triádico - Produção, Recepção e Transmissão - delineado por ele "responde a uma ideia de literatura como 'tipo de comunicação inter-humana' e 'sistema simbólico'. Cotejando os esquemas de Jakobson e Candido, Campos quer, dentro de uma perspectiva linguístico-estrutural, “estudar as 'funções da linguagem' e, entre elas, definir o lugar da 'função poética”. Depois de subsumir um modelo noutro, sua conclusão é a de que "entre os três elementos que se conjugam no modelo [de Candido], a MENSAGEM (o texto, a informação estética, a obra) não é posta em relevo; antes, a ela se alude metonimicamente, pois a ênfase é dada ao MECANISMO TRANSMISSOR, ao veículo da transmissão, e não propriamente a TRANSMISSÃO em si mesma, À MENSAGEM TRANSMITIDA, à sua materialidade enquanto TEXTO" (CAMPOS, 1989, p. 21). Dessa forma, arremata, "O modelo semiológico, articulado por Candido para descrever a formação da literatura brasileira, privilegia as funções EMOTIVA e REFERENCIAL [latentes na literatura romântica], acopladas na função COMUNICATIVO-EXPRESSIVA de exteriorização das 'veleidades mais profundas do indivíduo' e de 'interpretação das diferentes esferas da realidade”' (CAMPOS, 1989, pp. 26-27). Esse modelo, como ele vai assinalar, é o que foi perseguido por toda a historiografia literária do século XIX que, dentro do critério diacrônico, tentou mostrar a evolução da autonomia literária de cada nação:

\footnotetext{
A exclusão - o "sequestro" - do Barroco na Formação da Literatura Brasileira não é, portanto, meramente o resultado objetivo da adoção de uma "orientação histórica", que timbra em separar literatura, como "sistema", de "manifestações literárias" incipientes e assistemáticas. Tampouco é "histórica", num sentido unívoco e objetivo, a "perspectiva" que dá pela inexistência de Gregório de Mattos para efeito da formação de nosso "sistema literário" (...). Essa exclusão - esse sequestro - e também essa inexistência literária, dados como "históricos" no nível manifesto, são, perante uma visão "desconstrutora", efeitos, no nível profundo, latente, do próprio "modelo semiológico" engenhosamente articulado pelo autor da Formação (CAMPOS, 1989, p. 32).
}

Nesse modelo que valoriza particularmente as manifestações literárias do Romantismo e, especificamente, a história diacrônica - "evolutivo-linear-integrativa” -, "que enfatiza o aspecto 'comunicacional' e 'integra- 
tivo' da atividade literária”, "não cabe o Barroco, em cuja estética são enfatizadas a função poética e a função metalinguística, a auto-reflexividade do texto e a autotematização inter-e-intratextual do código (meta-sonetos que desarmam e desnudam a estrutura do soneto, por exemplo; citação, paráfrase e tradução como dispositivos plagiotrópicos de dialogismo literário e desfrute retórico de estilema codificado)" (CAMPOS, 1989, p. 33). Como o modelo de Candido vê literatura como sistema, fazendo-se necessário não somente a existência de um produtor e de um meio transmissor, mas, principalmente, de um receptor, Campos lembra que

\begin{abstract}
Resolver tais questões no plano recepcional não pode consistir em simplesmente postularque, ondenão haja um público "sistêmico" (denso, concorde, integrado), não haverá literatura propriamente dita e digna de registro - não haverá história avaliável em termos formativos - mas tão-somente "manifestações literárias", cenário "ralo" e "esparso", limbo afônico ("sem ressonância”) onde a voz do ser ainda não se "encorpou”, pré-história (in)forme inexistente em "perspectiva histórica” (...) Que aconteceria se tivéssemos de avalizar por um semelhante critério "sistêmico" a existência literária de produções tão remotas no tempo (e só recuperadas pelos eruditos depois de séculos de olvido) como as da poesia provençal, por exemplo? (CAMPOS, 1989, pp. 42-43).
\end{abstract}

Campos distingue duas situações às quais uma obra está submetida: a recepção entre os contemporâneos e no decorrer da história. A recepção

(...) envolve fases de opacidade ou de prestígio, de ocultação ou de revivescência. Que não sealimenta do substancialismo de um "significado pleno" (hipostasiado em "espírito" ou "caráter nacional"), rastreado como culminação de uma origem "simples", dada de uma vez por todas, "datável". Poderemos imaginar assim, alternativamente, uma história literária menos como formação do que como transformação. Menos como processo conclusivo, do que como processo aberto. Uma história onde relevem os momentos de ruptura e transgressão e que entenda a tradição não de um modo "essencialista" (...), mas como uma "dialética da pergunta e da resposta", um constante e renovado questionar da diacronia pela sincronia (CAMPOS, 1989, pp. 62-63).

\title{
V
}

Aparentemente estamos diante de um impasse, pois as linhas teóricas perseguidas por Campos e Candido são, em princípio, “inconciliáveis”. Impasse que parece tão mais complexo se não conseguirmos transcender as três bases de reflexões aqui colocadas: a que vê a literatura a partir de uma perspectiva diacrônica, como sistema, estrutura, forma 
orgânica (Candido); a que, ainda dentro de uma perspectiva diacrônica e nacionalista, retoma os pressupostos do historicismo determinista oitocentista, através do conceito de obnubilação (Coutinho); e, por fim, a que busca, por meio de cortes sincrônicos, ressaltar a literatura de invenção, estético-criativa (Campos). Vamos por etapas.

1. Ao buscar reescrever a história da literatura no Brasil, subtraindo do campo da crítica os princípios que privilegiam as funções "emotiva” e "referencial", e os substituindo pelo critério estético-criativo, as funções poéticas e metalinguísticas, Haroldo toma Gregório como uma espécie de "verbo" primaveral de uma nascente literatura pátria. O bardo baiano torna-se, assim, aquele que teria, já no século XVII, fundado (mesmo que essa não fosse sua intenção, nem ele tivesse tal consciência) não somente os fundamentos da alteridade entre o que viria a ser, no futuro, o que os românticos denominariam de literatura brasileira, mas o que ele - Haroldo de Campos - acata como uma literatura pátria com "L" maiúsculo: aquela que transgride a norma vigente e reoxigena a própria literatura que vinha sendo escrita em língua portuguesa. Ora, sendo Gregório o início dessa literatura pátria com "L" maiúsculo, a acepção de Campos de "uma história literária menos como formação do que como transformação; menos como processo conclusivo, do que como processo aberto", fica em suspenso. Pois se Candido, seguindo a filologia de um Eric Auerbach ou de um Ernst Robert Curtius, persegue uma história da literatura brasileira sem apelar para uma ideia de completude - marcando a sua formação em 1750 e encerrando o seu livro antes de Machado de Assis iniciar a sua produção literária (Cf. WAIZBORT, 2007, p. 94) -, Campos delimita o marco em que essa "poesia brasileira de invenção" teve inicio entre nós. Ou seja, o início da transformação se dá com a obra de Gregório. Assim, fica excluído qualquer processo de intertextualidade que, por ventura, sua obra possa sinalizar.

2. Se o modelo histórico-diacrônico, de base romântica, é acusado por Campos de ideológico, o critério sincrônico por ele defendido, enquanto conhecimento que se quer "verdadeiro" dos fenômenos estético-literários (seja como crítico historicamente situado, seja enquanto sistema de ideias ou como conjunto de valores articulados) é também, ao seu modo, ideológico.

3. Apesar dos pressupostos teórico-metodológicos distintos, Candido e Coutinho continuam prisioneiros do que foi firmado no século XIX: o modelo de uma crítica literária que está subordinada ao conceito de Nação, 
de Identidade Nacional e Cultural, de alteridade literária e linguística. Mesmo criticando esse modelo de história e de crítica literárias, todo o esforço de Campos está em resgatar o Barroco e sua "ação duradoura" e, por extensão, Gregório de Matos, como o início de uma história de uma literatura brasileira ou de uma antologia da literatura brasileira de invenção. Assinale-se que não interessa a Campos constituir uma Antologia da Poesia de Língua Portuguesa de Invenção - revelando as intertextualidades entre os que fazem uso de uma mesma língua, indiferentemente do critério de nacionalidade e territorialidade, ampliando ou redimensionando o conceito de sistema literário defendido por Candido - mas sim uma antologia dos que, sendo brasileiros, vão formar um paideuma nacional: literária e linguisticamente distintos dos demais escritores e falantes da língua de Camões. A Colônia não seria apenas o Outro do Eu português, mas o Outro que desde o principio se insurge contra os cânones literários vigentes na Metrópole. E se insurge pelo modo "estético-criativo". A passagem da "tocha entre corredores" sai, assim, de uma perspectiva diacrônica e dá lugar ao princípio sincrônico: o que renova as formas e o “repertório de informação estética”, o que privilegia antes as rupturas da linguagem do que a continuidade por "denominadores comuns".

Neste ponto, as reflexões teóricas de Candido e de Campos se mostram inconciliáveis. Pois, se é verdade que um autor que não teve a sua obra publicada não existe literariamente em perspectiva histórica, enquanto parte de um "sistema literário" calçado em cima da passagem da tocha entre corredores, não é menos verdade que quando da publicação da sua obra (mesmo que ela se dê um século depois da morte desse autor) sua existência em dada literatura não pode ser ignorada. Se o pressuposto de Candido é correto, é também insuficiente para apreender outros fenômenos da realidade literária. $\mathrm{O}$ primeiro deles é o continuum processo de intertextualidade entre as obras, indiferente de tempo, nacionalidade e espaço históricos. O segundo é o que permite que uma espécie de deus ex machina literário "embaralhe" a "ordem" dos corredores que, diacronicamente, passam a tocha para os que lhes sucedem. A ideia de sistema, dentro de um modelo diacrônico, não contempla o fato de que o Gregório resgatado no século XIX não foi lido do mesmo modo semanticamente e esteticamente - que os seus contemporâneos o leram. Hipoteticamente, caso a sua obra tivesse sido publicada nos seiscentos, ela estava fadada a dois destinos. O primeiro, ficar circunscrita apenas ao seu tempo, como ocorreu com inúmeras obras cujas "eficácia estética" e 
"potencial semântico" ${ }^{6}$ envelheceram na passagem de uma geração para outra; o segundo, era a sua obra ir além do seu tempo histórico-estético, transmitindo a sua "tocha" para as várias gerações futuras. Neste caso, pode ser indiferente o fato de Gregório ter sido publicado nos seiscentos ou apenas nos oitocentos, pois a "tocha” passada aos "corredores" dos séculos XIX e XX é distinta da que seria entregue aos "corredores" do século XVIII. Dessa forma, Gregório de Mattos - assim como qualquer outro escritor da língua portuguesa ou não (podemos excluir a influência de Shakespeare quando pensamos o teatro ocidental nos últimos 250 anos, ou a sua obra só é válida dentro do sistema literário de língua inglesa?) - se insere no sistema literário tanto pelo método diacrônico quanto pelo sincrônico.

Porém, não são apenas Coutinho e Campos que seveem em dificuldade na hora de pensar a produção intelectual e literária que foi desenvolvida por mazombos nos primeiros três séculos da colonização brasileira. Apesar das escolas teóricas que se sucederam ao longo do século XX e da literatura pátria ser lida pelo viés diacrônico ou sincrônico, o conceito de autonomia literária continua subordinando-as. Se, em Coutinho e Campos, a preocupação é como se deve resgatar a literatura produzida no Brasil Colônia e inseri-la como parte do cânone de uma literatura brasileira, em Candido o conceito de sistema literário impede-lhe de ver que aquilo que ele chama de "manifestações literárias" são, na verdade, obras que podem estar fazendo parte de outro sistema literário e, nesse caso, essas obras e seus "denominadores comuns" deixam de serem meras "manifestações literárias" e passam a existir historicamente; elas passam a existir historicamente por motivos diversos dos que são apregoados tanto por Candido quanto por Coutinho e Campos.

Embora o exemplo de Gregório dado por Candido encerre uma coerência lapidar, dentro da sua ideia fechada de sistema, os dois outros exemplos dados por ele de manifestações literárias - Antônio Vieira e João de Brito Lima - escondem as armadilhas que a sua teoria encerra. Vejamos.

1. Poucos intelectuais dos seiscentos português exerceram tanta influência junto aos seus mandatários, aos Jesuítas e à Cúria Romana (chegou a ser convidado para ser confessor do papa) quanto o padre Antônio Vieira. E o melhor exemplo está quando da publicação dos

6 Valho-me aqui de terminologias que foram usadas por Silviano Santiago (1989, pp. 215232) em ensaio que discute a sobrevivência de uma obra artística para além da sua "história social". 
Sermões. A correção dos manuscritos teve início na década de 60 do século XVII, e a sua publicação a partir de 1679, pela Oficina de João da Costa, em Lisboa. Até o ano da sua morte, em 1697, Vieira publicou 11 dos 15 volumes previstos, sendo que apenas parte do $14^{\circ}$ volume (lançado em 1710) e a totalidade do $15^{\circ}$ tomo - que veio à luz somente em 1748 não passaram pela sua revisão (Cf. MAGNE, 1943, pp. V-XIV). Tanto em língua portuguesa quanto em outras línguas europeias, os seus Sermões tiveram várias edições ao longo dos séculos XVIII e XIX. Informa-nos o padre Gonçalo Alves (1951, pp. XIV-XV) que editores de Madri, Barcelona e Saragoça disputavam as traduções e os lançamentos dos Sermões. Na Itália, durante toda a segunda metade dos Seiscentos, vieram a lume edições em Roma (1699), Veneza (1690; 1697)7 e Nápoles (1688). Outras edições foram publicadas em Colônia $(1692 ; 1708 ; 1727)$ e na Áustria. Assim, diante de tal demanda intelectual, como Vieira poderia ser considerado apenas

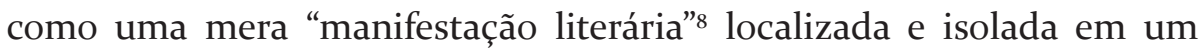
determinado momento histórico da Colônia, se ele vai ser lido, apreciado e/ou refutado ao longo dos séculos XVIII e XIX? Ou seja: apesar de ser um dos intelectuais mais respeitados e lidos do século XVII português, Vieira não teria existido enquanto perspectiva histórica, como quer Candido?

2. O nome de João de Brito e Lima, autor de obras poéticas publicadas em Lisboa, parece também implodir o exemplo de Candido, pois, como ele próprio lembra, seu nome consta - de maneira elogiosa e com certo destaque - na Biblioteca Lusitana do abade Diogo Barbosa Machado (1747, pp. 616-17).

Qual é o xis da questão?

Dentro do modelo de história literária firmado no século XIX, terminamos sempre por acatar o que se produziu em solo pátrio como literatura nacional (o inverso parece ser constituir em uma atitude de lesapátria). Se foi escrito em solo brasileiro, logo tal obra é parte integrante

7 Segundo o padre Gonçalo Alves, exemplares dos Sermões de Vieira foram publicados em Roma entre 1663 e 1699 e, em Veneza, saiu uma edição em 1673 . Como o $1^{\circ}$ volume dos Sermões só saiu em Portugal 1679, Alves não explica como as traduções para o italiano saíram antes da edição em português.

8 De fato, talvez a obra de Vieira não possa ser incluída como "manifestações literárias", já que sua obra não pode ser definida, stricto sensu, como literatura (a não ser que acatemos o critério formalista de literariedade), apesar da inegável beleza retórica que encerra. "Manifestação intelectual" talvez fosse um termo mais adequado para definir sua presença/ausência no Brasil seiscentista. Mas isso já é assunto para outro trabalho crítico. 
do nosso cânone literário. Se esse cânone tem início com Anchieta, Gregório de Matos ou com Cláudio Manuel da Costa, é uma "mera" questão de abordagem teórico-metodológica. O certo, dentro do modelo de historiografia literária (sincrônica ou diacrônica), é que se encontrem marcas textuais e formais que revelem a sua nacionalidade. Ou seja, se há intertextualidade entre as obras, esta só pode existir entre as que nasceram no mesmo solo pátrio. Quando se dá entre obras de nacionalidade distintas, suas formas literárias e seus temas têm, necessariamente, de serem aclimatados.

O xis da questão está no fato de que as obras produzidas no Brasil, nos primeiros três séculos da sua colonização, não foram meras "manifestações literárias" isoladas (como quer Candido), já que todas elas - indiferentemente de se foram ou não publicadas em livros - pertenciam a um dado sistema literário. Só que esse sistema literário ou intelectual não era o brasileiro (como o historicismo literário do século XIX forjou, e Coutinho e Campos, por vias diversas, acataram) - e, sim, o sistema literário português, uma vez que aqui não existiam nem editoras muito menos leitores em número significativo. Além desses escritores serem leais súditos da Coroa e integrantes da "casta" de scholares que mantinham a máquina estamental, era em Portugal que suas obras eram impressas e lidas. Basta lembrarmos a Prosopopeia, de Bento Teixeira, publicada em Portugal em 1601, numa edição de um milheiro, mas que nunca circulou na Colônia (Cf. MELLO, 1969, pp. VII-XI). E não podia ser diferente, já que Bento Teixeira, assim como Vieira e João de Brito Lima, se sentiam lusitanos e partícipes da sua vida intelectual. O mesmo ocorrendo com Diogo do Couto, Bento de Góes, António de Andrade e Fernão Álvares do Oriente que escreveram sobre o mundo que o português vinha criando, mas que tinham consciência de que pertenciam a um dado sistema intelectual - o português - e que era nesse dado sistema que estava o seu público leitor.

Apesar de muitos dos sermões de Vieira terem como primeiro público-alvo os mazombos, ele sabia que seus livros pouco circulariam na Colônia. Era na Corte que o seu prestígio intelectual e político crescia, ele se consolidava como um dos mais importantes intelectuais do seu tempo, sua obra seria publicada e lida e de onde os seus textos passariam a ecoar para o resto da Europa. Os "denominadores comuns" da sua obra eram os que prevaleciam na Corte. Se, na segunda metade do século XVIII, os poetas da América Portuguesa eram árcades, enquanto a Alemanha e 
a Inglaterra já firmavam os primeiros passos da estética romântica, era porque Portugal ainda era árcade.

De alguma maneira, Candido parece acatar essa realidade do escritor que nasceu ou residiu no Brasil - aqui escrevendo, mas publicando em Portugal - quando defende que sendo a literatura brasileira ramo da portuguesa (mesmo que secundário), a atenção do seu estudo "se volta para o início de uma literatura propriamente dita, como fenômeno de civilização, não algo necessariamente diverso da portuguesa. Elas se unem tão intimamente, em todo caso, até meados do século XIX, que utilizo em mais de um passo, para indicar este fato, a expressão 'literatura comum' (brasileira e portuguesa)" (CANDIDO, 1981, p. 28). Como já assinalou Guilherme Simões Gomes Júnior (1998, p. 156), se há uma literatura comum, "pressupõe-se um mesmo e único 'sistema' letrado que, certamente, a despeito de envolver Brasil e Portugal, não é brasileiro e nem mesmo português e está baseado em princípios razoavelmente distintos do modelo estabelecido por Antonio Candido logo no primeiro segmento do livro".

Apesar do alargamento conceitual da sua ideia de "sistema literário", Candido incorre em um erro de base epistemológica, posto que ele está admitindo, por subtração ou por adição (o critério fica ao gosto do leitor), a existência de uma literatura brasileira convivendo, ou mesmo se urdindo, com uma literatura portuguesa. O que, em tese, contradiz seu conceito de "manifestações literárias" em relação às obras que foram escritas e publicadas por aqueles que viveram na Colônia. Se são "manifestações literárias", não é "literatura propriamente dita" - literatura "como fenômeno de civilização" -, logo, não existe nesse período em estudo uma "literatura brasileira". Não existindo, ela não pode ser "comum" com a portuguesa, pois como esta já existia como "literatura propriamente dita", o que a conduz a ser "comum" com uma literatura que não existe enquanto "fenômeno de civilização"? Por outro lado, se já existe uma literatura brasileira desde o século XVI, está instituída a existência de um sistema em construção, realidade muito distinta do conceito de "manifestações literárias". Ademais, o conceito de literatura nacional pressupõe a existência de uma ideia de Nação. Logo, de Identidade Cultural. Se essa Identidade inexistia numa região que desconhecia a si mesma (o Brasil era constituído de ilhas populacionais isoladas, que mantinham relações antes com a Metrópole do que entre si), como falar de tal conceito? 
Ainda prosseguindo nesta questão, discordamos de Guilherme Simões Gomes Júnior quando afirma que se há uma literatura comum, “pressupõe-se um mesmo e único 'sistema' letrado que, certamente, a despeito de envolver Brasil e Portugal, não é brasileiro e nem mesmo português". Ora, não há "literatura comum" porque não há duas literaturas distintas, que se complementam; o que há é única e somente uma só literatura: a portuguesa e, por sua vez, um sistema literário português que compreende ou encerra as ditas "manifestações literárias" defendidas por Candido. O que faz, desse modo, com que essas ditas "manifestações literárias” não sejam "manifestações literárias”, mas sim obras literárias "propriamente ditas" - literatura "como fenômeno de civilização" - que pertenciam e enriqueciam um certo sistema literário que, no caso, era o português.

\section{VII}

Se o espírito da modernidade começa a se forjar por volta do século XII, com os embates da crise doutrinal entre universalistas e nominalistas, com as reformas do processo judicial, com a criação do purgatório e, principalmente, com o advento de uma nova subjetividade - a razão moderna - (Cf. VAZ, 2002; LIMA, 1989, pp. 11-51; ROUANET, 1993, pp. 4695), o fato é que só a partir de escritores como Shakespeare e Cervantes é que vemos nascer a ideia de indivíduo tal como a entendemos hoje; o que Georg Lukács (2000, pp. 30) denominou de a "produtividade do espírito" e o Eu como a "única substância verdadeira". Para o autor de $A$ Teoria do romance, o homem moderno teve de "cavar abismos intransponíveis entre conhecer e fazer, entre alma e estrutura, entre eu e mundo, e permitir que, na outra margem do abismo, toda a substancialidade se dissipasse em reflexão" (LUKÁCS, 200o, pp. 30-31). Ou seja, a totalidade ontológica, essencial, entre o Eu e o Outro, o Eu e o mundo, foi passo a passo se dissolvendo ao tempo que a "vida essencial" da Idade Média ia pouco a pouco entrando em colapso. A homogeneidade entre o Eu e o Outro se mostrava cada vez mais distante. Os deuses e as intervenções do maravilhoso tinham abandonado os homens: Hamlet e Dom Quixote são os exemplos mais acabados dessa dissolução. Cada um, ao seu modo, tem que lidar com sua própria consciência. Um, pela angústia de saber que o destino do seu reino só depende de si; não há, como em Orestes, 
de Eurípedes, um deus ex machina que venha lhe salvar dos dilemas do seu reino e dos que atordoam a sua consciência. Outro, o Cavaleiro da Triste Figura, se evade no sonho e na imaginação para recuperar, através da crença em personagens de papel, um tempo que o próprio tempo e os homens se empenharam em diluir em pó. Ainda segundo Lukács (2000, p. 31): a "Totalidade do ser só é possível quando tudo já é homogêneo, antes de ser envolvido pelas formas; quando as formas não são uma coerção, mas somente a conscientização, a vinda à tona de tudo quanto dormitava como vaga aspiração no interior daquilo a que se devia dar forma; quando o saber é virtude e a virtude, felicidade; quando a beleza põe em evidência o sentido do mundo".

É dessa angustiante realidade que parece tratar quase toda a literatura moderna; realidade que foi verticalizada ainda mais pela geração romântica: onde o Eu subjetivo (avesso aos manuais de poética que normatizavam e regiam as artes, traduzindo os valores dos estamentos sociais dominantes) encerra cada vez mais o poeta em seu próprio universo. É com esta geração, particularmente a partir de um Baudelaire, que o poema passa a oscilar "entre a comunicação da linguagem e a autonomia da arte e, por isso, a sua forma de designação inclui, substancialmente, a tensão entre dois polos" (BARBOSA, 1986, p. 35).

As perguntas não enunciadas, mas que urdem e perseguem este ensaio, são duas. A primeira, mais explícita, persegue a ideia romântica do "territorialismo ansioso" (WELLBERY, 1998, p. 27) no campo das artes, mais particularmente, no das letras. Territorialismo este que, em Candido (1981, p. 25), se dá pela tese de que a nossa literatura não é causa da obnubilação da sua gente, mas do desejo dos brasileiros em ter uma literatura nacional e, principalmente, como eles, os brasileiros, partindo da "síntese de tendências universalistas e particularistas", moldaram localmente as tendências universalistas ao urdir texto e contexto. Partindo de uma "interpretação dialeticamente íntegra", Candido mostra como nasceu o nosso sistema literário, a nossa "literatura propriamente dita”. A segunda pergunta, implícita, mas basilar para se discutir o "territorialismo ansioso" das literaturas nacionais, é: se a literatura que nasce com Shakespeare e Cervantes "busca descobrir e construir, pela forma, a totalidade oculta da vida”, como notou Lukács, como se dá, dentro dessa realidade ontológica, a construção ou a formação de uma literatura nacional? Se cada poeta constrói seu discurso a partir de si, 
em uma angústia incessante entre "a comunicação da linguagem e a autonomia da arte”, e não mais como voz de uma dada comunidade, como fizera Homero, como pode sua obra encerrar e urdir o Eu e o Outro, o Sujeito e o Objeto?

É neste ponto, creio, que as histórias literárias, assim como um uroboro (a serpente que come a própria cauda), enroscam-se em si mesmas. Pois como encontrar um sistema literário coeso, fruto de um desejo coletivo, quando o escritor já não se propõe a ser, já não se coloca mais como um Homero da coletividade? Talvez as histórias literárias sofram das mesmas angústias que marcam o escritor moderno: o da busca da "totalidade oculta da vida". Só que esta totalidade não é mais a do Eu com o mundo, como persegue o poeta, mas a do Eu com a Nação, com aqueles que nasceram em solo comum, que compartilham de um mesmo código linguístico, que acreditam que em suas veias correm um mesmo sangue ancestral, que se irmanam numa identidade cultural. Há, em toda história literária, a mesma pergunta que nasceu com a epopeia: como pode a história e a vida de um dado povo se tornar "essencial"? Como, para pensar como Candido, texto e contexto se urdem para construir um sistema literário que traduza e, por sua vez, seja traduzido como o espírito coletivo de uma dada nação? Pois, se texto e contexto se urdem em Shakespeare e Cervantes para, através da forma literária, se tentar apreender a "totalidade oculta da vida", creio que as histórias literárias saem em busca não de entender e apreender o Ser em toda sua complexidade, indiferente da nacionalidade, mas de tentar forjar somente a compreensão de um Ser nacional (projeto mais do que urgente dentro do conceito de nação). Daí talvez a exclusão ou o pouco caso com escritores e poetas que fogem dessas marcas que formam os "denominadores comuns" e, por sua vez, da "essência" do que se busca acatar como uma literatura nacional.

Lembra-nos João Cezar de Castro Rocha (2008, p. 31), que o esforço de Candido "supõe a possibilidade de uma história literária que, sem abdicar do conceito de nação - entendido enquanto lugar próprio de determinação de sentido -, afasta-se da ideia de nacionalidade - compreendida enquanto matriz determinadora de um sentido único e tautológico: o da própria nacionalidade". Ora, se a nação, no caso brasileiro, é fruto de uma construção ideológica do Estado politicamente autônomo que nasce em 1822, logo, o desejo de se construir uma literatura era também movido, em suas bases, pelo afã de se construir uma nacionalidade até então 
inexistente. Basta lembrar que o conceito de "sistema literário" passa pela ideia de "obras ligadas por denominadores comuns, que permitem reconhecer as notas dominantes de uma fase", a exemplo da língua, dos temas e das imagens. E o que é a busca de denominadores comuns se não a busca de "um sentido único e tautológico"? Quando Candido (1989, p. 148) acusa os escritores simbolistas e Parnasianos de assimilarem "as formas e valores da moda europeia", assinalando que "pela falta de pontos locais de referência, [seus poemas] podiam não passar de exercícios de mera alienação cultural, não justificada pela excelência da realização", não há aí uma acusação de quem não reconhece nesses poetas a inscrição num dado sistema literário, exatamente pela ausência de pontos locais de referências, temas e imagens comuns, ou melhor, os tais "denominadores comuns" que formaram a alteridade entre a literatura brasileira e as demais literaturas nacionais? E o que são essas referências de temas e imagens comuns se não o sentido "único e tautológico" de uma literatura que busca se urdir com o desejo dos brasileiros de serem também uma nação e, por sua vez, de construírem sua nacionalidade?

Se Candido, de fato, como quer Castro Rocha, afasta-se da ideia de nacionalidade em Formação da literatura brasileira, por que a literatura dos parnasianos e simbolistas é um "exercício de mera alienação cultural”? Mallarmé, para ficar num outro sistema literário, o francês, é menos filho da literatura francesa do que Victor Hugo? Talvez, creio, tal acusação se dá porque se a poesia de Cruz e Souza e Olavo Bilac busca a "totalidade oculta da vida" por meio da oscilação "entre a comunicação da linguagem e a autonomia da arte", ela também se revela uma nota dissonante na relação entre texto e contexto, entre o texto e o seu referente. Relevado o referente, como encontrar a unidade dos temas e das imagens comuns que constituem o sistema literário? Talvez esteja aí a explicação para se entender por que os parnasianos e simbolistas foram não somente vítimas da incompreensão da Geração crítica de 1870 - Sílvio Romero à frente -, mas também, o que me parece mais grave, dos modernistas de 1922. Se a geração de Romero não tinha ferramentas teóricas para ler e entender a poesia de Cruz e Souza e Bilac, o mesmo não se poderia dizer da geração de 22, muito menos daquele que, com sua obra crítica, dá prolongamento, segundo Abel Barros Baptista (2005, p. 43), ao "projeto literário do Modernismo de 22": Antonio Candido.

Retomo a pergunta anterior: se, na modernidade, cada poeta constrói seu discurso a partir de si, em uma angústia incessante entre 
“a comunicação da linguagem e a autonomia da arte", e não mais como voz de uma dada comunidade, como fizera Homero, como pode, agora, a poesia encerrar e urdir o Eu e o Outro, o Sujeito e o Objeto? Enfim: como pode essa obra se inscrever em um projeto comum que busca construir uma literatura nacional? O fato é que as obras de Cruz e Souza e de Bilac se revelam tão "excêntricas" para quem busca abordar uma dada literatura nacional fundada em "denominadores comuns" quanto para as vozes isoladas que, vivendo num território inóspito - a Colônia -, escreviam seus versos para serem lidos na Metrópole distante. Em comum entre uma e outra: um referente pouco substantivo, esfumaçado, que não permite ao crítico de formação sociológica articular texto e contexto. No caso dos poetas coloniais, creio que a ausência de um referente que permitisse ao crítico ver como a forma literária foi alterada pelo contexto (pois as formas literárias verificadas nas produções da colônia eram as mesmas da Metrópole) pesou em sua decisão de tomá-las em bloco como meras "manifestações literárias”. Já em Cruz e Souza e Bilac, se não se podia acusá-los de serem "manifestações literárias" (pois ambos estão contextualizados dentro de um dado "sistema literário"), a "falta de pontos locais de referência” (a forma literária adotada seria alheia ao contexto) permitiu ao crítico acusá-los de praticarem "exercícios de mera alienação cultural". Suas obras, nada obstante serem "ligadas por denominadores comuns", não permitem a Candido reconhecer "as notas dominantes de uma fase". Ora, nada mais falso, pois as "notas dominantes" encontram-se lá em seus versos, o que não encontramos nessa produção poética, salvo melhor juízo, são os temas, as imagens, a natureza social e psíquica dos que perseguiam um projeto coletivo de literatura a partir de um referente comum, dos que buscavam urdir sujeito, nação e nacionalidade como um todo coerente. Num caso e noutro, a teoria e o método da crítica revelam seus limites: os limites de quem subordina a literatura - o texto - a um contexto territorial - bases das histórias literárias nacionais.

\section{REFERÊNCIAS BIBLIOGRÁFICAS}

ALVES, Padre Gonçalo. Duas palavras de apresentação. In: VIEIRA, Padre Antonio. Sermões. Porto: Lello \& Irmão; Lisboa: Aillaud \& Lellos, 1951, pp. v-xxxvi. 15 vols., v. 1.

ARANTES, Paulo Eduardo; ARANTES, Otilia Beatriz Fiori. Providências de um crítico literário na periferia do capitalismo. In: Sentido da Formação: três estudos sobre 
Antonio Candido, Gilda de Mello e Souza e Lúcio Costa. São Paulo: Paz e Terra, 1997, pp. 7-66.

ARARIPE JÚNIOR. Tristão de Alencar. Literatura Brasileira. In: Obra crítica Araripe Júnior. Rio de Janeiro: Ministério da Educação e Cultura; Casa de Rui Barbosa, 1958, pp. 489497. V. 1, pp. 1868-1887.

BAPTISTA, Abel Barros. O Cânone como formação: a teoria da literatura brasileira de Antonio Candido. In: O Livro agreste: ensaio decurso de literatura brasileira. Campinas: Editora Unicamp, 2005, pp. 41-80.

BARBOSA, Afrânio Gonçalves. Fontes escritas e história da língua portuguesa no Brasil: as cartas de comércio no século XVIII. In: LIMA, Ivana Stolze; CARMO, Laura do. História social da língua nacional. Rio de Janeiro: Edições Casa de Rui Barbosa, 2008, pp. 181-211.

BARBOSA, João Alexandre. As Ilusões da modernidade. In: As Ilusões da modernidade: notas sobre a historicidade da lírica moderna. São Paulo: Perspectiva, 1986, pp. 13-37.

CAMPOS, Haroldo de. A Arte no horizonte do provável e outros ensaios. $3^{\circ}$ ed. São Paulo: Perspectiva, 1975 .

CAMPOS, Haroldo de. A operação do texto. São Paulo: Perspectiva, 1976.

CAMPOS, Haroldo de. O sequestro do barroco na formação da literatura brasileira: o caso Gregório de Mattos. Salvador: Fundação Casa de Jorge Amado, 1989.

CANDIDO, Antonio. (1959). Formação da literatura brasileira (momentos decisivos). $6^{\circ}$ ed. Belo Horizonte: Itatiaia, 1981, 2 v., $1^{\circ} \mathrm{v}$.

CANDIDO, Antonio. Iniciação à literatura brasileira. $4^{\circ}$ ed. revista. Rio de Janeiro: Ouro sobre azul, 2004 .

CANDIDO, Antonio.(1965). Literatura e sociedade: estudos de teoria e história literária. $8^{\circ}$ ed. São Paulo: T.A. Queiroz Editor, 2000.

CANDIDO, Antonio. Literatura e subdesenvolvimento. In: A Educação pela noite $\mathcal{E}$ outros ensaios. São Paulo; Ática, 1989, pp. 140-162.

CASTRO, Yeda Pesoa de. Os aportes africanos no Brasil, vistos de novo. In: GALANO, Ana Maria; CAPINHA, Graça; FRÓES, Leonardo; KURY, Lorelai. (orgs.). Língua Mar: criações e confrontos em português. Rio de Janeiro: Funarte, 1997, pp. 57-66.

COUTINHO, Afrânio. (1960). Conceito de literatura brasileira. Petrópolis: Vozes, 1981.

COUTINHO, Afrânio. (1953). Correntes cruzadas (questões de literatura). In: Crítica e teoria literária. Rio de Janeiro: Tempo Brasileiro; Fortaleza: Universidade Federal do Ceará, 1987, pp. 19-182. 
410 - Remate de Males 36.2

COUTINHO, Afrânio (1957). Da Crítica e da nova crítica. $2^{\circ}$ ed. Rio de Janeiro; Civilização Brasileira, 1975.

COUTINHO, Afrânio. (1968). Crítica e poética. In: Crítica e teoria literária. Rio de Janeiro: Tempo Brasileiro; Fortaleza: Universidade Federal do Ceará, 1987, pp. 381-519.

COUTINHO, Afrânio. (1959). Introdução à literatura no Brasil. $17^{\circ}$ ed. Rio de Janeiro: Bertrand Brasil, 2001.

CURTIUS, Ernst Robert. (1948). Literatura europeia e Idade Média Latina. $2^{\circ}$ ed. Trad. Teodoro Cabral e Paulo Rónai. São Paulo: Hucitec; Edusp, 1996.

FERNANDES, Marcos Rogério Cordeiro. Sobre o método crítico de Antonio Candido em Formação da literatura brasileira. Revista do Centro de Estudos Portugueses, Belo Horizonte, v. 26, n. 36, jul./dez. 2006, pp. 225-242.

FONSECA, Maria Cristina de Assis. A escrita Oficial: manuscritos paraibanos dos séculos XVIII e XIX. Apresentação Marlos de Barros Pessoa. Recife: Programa de PósGraduação em Letras da UFPE, 2005a. (Coleção Teses).

FREYRE, Gilberto. (1933) Casa-grande E senzala. $23^{\circ}$ ed. Rio de Janeiro: José Olympio, 1984 .

FRYE, Northrop. Fábulas de identidade: estudos de mitologia poética. Trad. Sandra Vasconcelos. São Paulo: Nova Alexandria, 2000.

GOMES JÚNIOR, Guilherme Simões. Palavra peregrina: o Barroco e o pensamento sobre artes e letras no Brasil. São Paulo: Edusp; Fapesp; Educ, 1998.

HOUAISS, Antônio. O estigma de um debate. Folha de São Paulo, São Paulo, caderno Folhetim, 9 jun. 1985, pp. 6-8.

JAKOBSON, Roman. Linguística e poética. In: Linguística e comunicação. Prefácio de Izidoro Blikstein; trad. De Izidoro Blikstein e José Paulo Paes. 14 ed. São Paulo: Cultrix, 1991, pp. 118-162.

LAJOLO, Marisa. A leitura na Formação da Literatura Brasileira de Antonio Candido. In: SERNA, Jorge Ruedas de la. História e literatura; homenagem a Antonio Candido. Campinas: Ed. da Unicamp; São Paulo: Memorial da América Latina; Imprensa Oficial do Estado, 2003, pp. 51-75.

LIMA, Luiz Costa. O Controle do imaginário: razão e imaginação nos tempos modernos. $2^{\circ}$ Ed. Rio de Janeiro: Forense Universitária, 1989.

LUKÁCS, Georg. (1920). A Teoria do romance: um ensaio histórico-filosófico sobre as formas da grande épica. Trad. José Marcos Mariani de Macedo. São Paulo: Editora 34, 2000 . 
MACHADO, Diogo Barbosa. João de Brito de Lima. In: Biblioteca lusitana. Lisboa: Officina de Ignácio Rodrigues, 1747, pp. 616-617, tomo II. Edição fac-similar: Coimbra: Atlântida Editora, 1966.

MAGNE, Padre Augusto. Explicação preambular. In: VIEIRA, Padre Antônio. Sermões do Padre Antônio Vieira. São Paulo: Anchieta, 1943, pp. V-XIV. 15 V, ํํv. Reprodução facsimilada da edição de 1679 .

MELLO, José Antônio Gonsalves de. Prefácio. In: PILOTO, Afonso Luiz; TEYXEYRA, Bento. Naufrágio e Prosopopeia. Introdução, notas e glossário Fernando de Oliveira Mota. Recife: UFPE, 1969, pp. VII-XI.

PINTO, Edith Pimentel. A Língua escrita no Brasil. São Paulo: Ática, 1986.

RAMOS, Maria Ana. Que língua é a língua dos ciganos vicentinos? In: BRILHANTE, Maria João et all. Gil Vicente: 500 anos depois. Lisboa: Imprensa Nacional - Casa da Moeda, 2003, pp. 151-177, v. II. [Actas do Congresso Internacional realizado pelo Centro de Estudos de Teatro da Faculdade de Letras da Universidade de Lisboa].

ROCHA, João Cezar de Castro. Uma história literária macunaímica. In : Exercícios críticos: leituras do contemporâneo. Chapecó: Argos, 2008, pp. 29-53.

ROUANET, Sérgio Paulo. A Coruja e o sambódromo. In : Mal-Estar na Modernidade. São Paulo: Companhia das Letras, 1993, pp. 46-95.

SANTIAGO, Silviano. Para além da história social. In: Nas malhas da letra. São Paulo: Companhia das Letras, 1989, pp. 215-232

SCHWARTZ, Stuart B. Burocracia e sociedade no Brasil colonial: a Suprema Corte da Bahia e seus juízes: 1609-1751. Trad.: Maria Helena Pires Martins. São Paulo: Perspectiva, 1979 .

SILVA, Rosa Virgínia Mattos e. Ensaios para uma sócio-história do português brasileiro. São Paulo: Parábola Editorial, 2004.

SPINA, Segismundo. Introdução. In: A poesia de Gregório de Matos. Prefácio de Haroldo de Campos. São Paulo: Edusp, 1995, pp. 17-88.

VAZ, Henrique C. de L. Raízes da modernidade. São Paulo: Edições Loyola, 2002.

WAIZBORT, Leopoldo. A passagem do três ao um: crítica literária, sociologia, filologia. São Paulo: Cosac Naify, 2007.

WELLBERY, David. E.; BENDER, John. Retoricidade: Sobre o retorno modernista da retórica. In: WELLBERY, David. E. Neo-retórica e desconstrução. Lima, L. C.; Kretschmer, J. (orgs.). trad.: Ângela Melim. Rio de Janeiro: UERJ, 1998, pp. 11-47. 